\title{
THERMAL RESISTANCE OF AIRFIELD CONCRETE PAVEMENTS AND CONSEOUENCES FOR THE MAINTENANCE THEREOF
}

\section{TERMICZNA ODPORNOŚĆ BETONOWYCH NAWIERZCHNI LOTNISKOWYCH I JEJ SKUTKI DLA PROCESU UŻYTKOWANIA}

\author{
Malgorzata Linek ${ }^{1}$, Patrycja Piotrowska-Nowak ${ }^{1}$, Piotr Nita ${ }^{2}$ \\ ${ }^{1}$ Politechnika Świętokrzyska w Kielcach, \\ ${ }^{2}$ Instytut Techniczny Wojsk Lotniczych w Warszawie
}

\begin{abstract}
The project presents the approximate method to specify temperature changes which may cause and intensify the pavement slabs destruction. Criteria of thermal concrete resistance in case of pavement structure were specified. Defining the acoustics performance, the degree of changes occurred in surface layer and changes in basic mechanical parameters as criteria of pavement thermal condition were suggested. The process of cement concrete damage in case of pavement structure, as a result of combined temperature changes and vehicle traffic was also discussed. Criteria of fragile damage of concrete slab and allowable stress of concrete layer in case of pavement structure were described. Types of heat flow within the pavement were discussed and associated with the occurred damages. The destruction process of concrete pavements under the influence of temperature was presented. The publication contains the proposal of reducing the effects of the aforementioned factors on the range of the occurred stress. The analysis does not include the complex issue of thermal stress within concrete pavement, caused by hot exhaust gas stream.
\end{abstract}

Keywords: airfield concrete pavements, thermal resistance, cement concrete, airfield pavements

Streszczenie: $W$ referacie przedstawiono przybliżony sposób określania zmian temperatury, które moga powodować i potegować uszkodzenia płyt w nawierzchni. Sformulowano i określono kryteria termicznej odporności betonu $w$ konstrukcji nawierzchni. Zaproponowano określenie charakterystyk akustycznych, stopnia wystepujacych zmian $w$ warstwie powierzchniowej oraz zmian $w$ wielkości podstawowych parametrów mechanicznych jako kryteria oceny stanu termicznego nawierzchni. Omówiono mechanizm niszczenia betonu cementowego $w$ konstrukcji nawierzchni na skutek tacznego oddziaływania zmian temperatury i ruchu pojazdów. Sformulowano kryteria kruchego niszczenia płyty betonowej oraz naprężeń dopuszczalnych dla warstwy betonu w konstrukcji nawierzchni komunikacyjnej. Omówiono modele przepływu ciepła $w$ nawierzchni i powiąano je z powstajacymi uszkodzeniami. Przedstawiono charakterystyke procesu niszczenia nawierzchni betonowych pod wplywem dziatania temperatury. W analizie nie uwzględniano złożonej problematyki naprężeń termicznych, $w$ nawierzchni betonowej, spowodowanych emisja strumienia gorących gazów spalinowych.

Stowa kluczowe: betonowe nawierzchnie lotniskowe, odporność termiczna, beton cementowy, nawierzchnie lotniskowe 
Thermal resistance of airfield concrete pavements and consequences...

Termiczna odporność betonowych nawierzchni lotniskowych i jej skutki...

\section{Wprowadzenie do zagadnienia termicznej odporności nawierzchni}

Nawierzchnie lotniskowe wykonane $\mathrm{z}$ betonu cementowego poddawane są cyklicznym zmianom temperatur, których pochodzenie jest wynikiem naturalnych procesów atmosferycznych. Najbardziej niekorzystnym zjawiskiem decydującym o dużej podatności nawierzchni na uszkodzenia temperaturowe ma oscylowanie temperatury w pobliżu ,zera”. Szacuje się, że na terenie naszego kraju w skali roku ilość przejść przez tak zwane „zero" wynosi około 170. [2] Obliczenia naprężeń w betonie nawierzchniowym będących skutkiem zmian temperatury powinny uwzględniać gradienty temperatur $\mathrm{w}$ górnej warstwie płyty. Wynoszą one około $20-30^{\circ} \mathrm{C}$ na $1 \mathrm{~mm}$ jej grubości. Wielokrotnie zmienne temperatury powodują wystąpienie określonych odkształceń w betonie powodując jego wytężenie, a w efekcie „termiczne zmęczenie betonu" w płycie nawierzchniowej. W sposób przybliżony można określić zmiany temperatury, które moga powodować uszkodzenia betonowych płyt nawierzchni. Propagujące $\mathrm{w}$ nawierzchni fale o charakterze termosprężystym wywołują zmienne stany naprężeń i odkształceń, a w konsekwencji stany "termicznego zmęczenia nawierzchni". Zależą one nie tylko od współczynników rozszerzalności termicznej materiałów, ale również od modułów sztywności poszczególnych warstw układu konstrukcyjnego. $\mathrm{W}$ analizie naprężeń termicznych należy wyróżnić i uwzględnić: prędkość rozchodzenia się poszczególnych rodzajów fal; współczynniki sprężystości E i $\mu$; impedancje falowe lub współczynniki refrakcji (odbicia i załamania na granicy ośrodków - warstw); rodzaj połączenia pomiędzy warstwami układu nawierzchni; współczynnik tarcia poruszających się po nawierzchni kół statków powietrznych oraz "dopasowanie termiczne pomiędzy warstwami". Dopasowanie termiczne rozumiane jest w tym przypadku, jako rezultat przepływu ciepła pomiędzy warstwami układu konstrukcyjnego. Jeżeli przepływ ciepła $\mathrm{r}=1$, to zachodzi przypadek pełnego dopasowania termicznego $\mathrm{w}$ warstwowym układzie konstrukcyjnym nawierzchni. Jeżeli $\mathrm{r}=0$, to występuje przypadek braku wymiany ciepła pomiędzy otoczeniem, a nawierzchnią. [4] W analizie należy uwzględnić zjawisko "dyfuzyjności cieplnej" nawierzchni, która jest specyficzną własnością materiału. Charakteryzuje ona przepływ ciepła $\mathrm{w}$ zmiennych warunkach oddziaływania termicznego. Jest to zdolność materiałów składowych nawierzchni jako reakcja na zmiany temperatury w czasie.

\section{Klasyczne rozwiązania dotyczące wyznaczenia naprężeń temperaturowych $\mathbf{w}$ betonowej płycie nawierzchni lotniskowych}

W dotychczasowej praktyce analizy rozkładu temperatury w nawierzchni betonowej po przyjęciu modelu półprzestrzeni sprężystej zmian temperatury odbywa się według funkcji przedstawionej zależnością (1), zgodnie z [1 i 7].

gdzie:

$$
\theta=\theta_{0} \sin \frac{2 \pi}{T} t
$$

$\theta$ - temperatura powierzchni płyty, po upływie czasu t od początku jej ogrzewania,

$\theta_{0}$ - amplituda wahań temperatury na powierzchni ogrzewanej płyty,

$\mathrm{T}$ - okres cyklu zmian temperatury,

t - czas, który upłynął od początku cyklu. 
W modelu tym, temperatura na dowolnej głębokości nawierzchni betonowej wyrażana jest zależnością (2) wg [1, 7].

$$
\theta_{z}=\theta_{0} e^{-\frac{z}{a_{p}} \sqrt{\frac{\pi}{T}}} \sin \left(\frac{2 \pi}{T} t-\frac{z}{a} \sqrt{\frac{\pi}{T}}\right)
$$

gdzie:

$\theta_{\mathrm{z}}$ - temperatura na dowolnej głębokości nawierzchni,

$\theta_{0}$ - amplituda wahań temperatury na powierzchni ogrzewanej płyty,

z - głębokość rozpatrywanej warstwy,

$\mathrm{T}$ - okres cyklu zmian temperatury,

t - czas, który upłynął od początku cyklu,

a - współczynnik dyfuzyjności cieplnej, wyznaczany z zależności (3) [1, 7]

$$
a=\sqrt{\frac{\lambda}{c \rho}}
$$

gdzie:

$\lambda$ - współczynnik przewodności cieplnej,

$\rho$ - gęstość materiału,

c - ciepło właściwe materiału,

Naprężenia termiczne na głębokości $\mathrm{z}$ określonego przekroju nawierzchni przedstawić można zależnością (4) [1]:

$$
\sigma_{x}=\sigma_{y}=\frac{E_{b} \varepsilon_{t}}{1-\mu}\left[-\theta_{z}+\frac{1}{h} F+\frac{12\left(\frac{h}{2}-z\right)}{h^{3}} S\right]
$$

gdzie:

$\mathrm{Eb}$ - moduł sprężystości betonu

et - współczynnik rozszerzalności termicznej

$\mu$ - współczynnik Poissona

$\mathrm{h}$ - grubość płyty

$F=\int_{0}^{h} \theta_{z} d z \quad$ - pole przekroju temperatury w przekroju pionowym płyty o grubości h

$S=\int_{0}^{h} \theta_{z}\left(\frac{h}{2}-z\right) d z$ - moment statyczny pola $\mathrm{F}$ względem poziomej osi przekroju pionowego płyty

W przypadku złożonego stanu naprężeń $\mathrm{w}$ płycie, a taki stan jest efektem jej normalnej pracy na lotnisku, należy ustalić kryteria termicznej odporności betonu. Kryteria te pozwolą na określenie stanu wytrzymałościowego płyty w różnych etapach jej eksploatacji. W publikacji nie uwzględniono zjawisk, które są następstwem nagrzewania płyty betonowej strumieniem gorących gazów emitowanych przez silniki statków powietrznych [6]. 
Thermal resistance of airfield concrete pavements and consequences...

Termiczna odporność betonowych nawierzchni lotniskowych i jej skutki...

Współczesne rozwiązania uwzględniają bardziej złożone kwestie takie jak np. dopasowanie termiczne warstw układu i konieczność modelowania przepływów ciepła mających miejsce w tych układach [5].

\section{Obecne kryteria termicznej odporności betonu w nawierzchniach lotniskowych}

W celu oceny stanu technicznego nawierzchni betonowej poddanej wielokrotnemu, zmiennemu działaniu wpływów temperatury należy dysponować odpowiednimi kryteriami. Aktualnymi kryteriami, które mogą być pomocne w ocenie termicznej odporności betonu są: wyniki obserwacji ciał próbnych wykonanych $\mathrm{z}$ betonu cementowego oraz obserwacje i pomiary poligonowe poczynione $\mathrm{w}$ warunkach rzeczywistych, głównie na wydzielonych, funkcjonalnych elementach systemu nawierzchni tj. na płaszczyznach prób silników. Jako kryteria oceny stanu technicznego lotniskowego betonu nawierzchniowego na obecnym etapie proponuje się:

- Określenie charakterystyk akustycznych, które mogą świadczyć o ewentualnym rozwoju zmian w strukturze betonu (mikrospękania i odspojenia warstw);

- Określenie stopnia zmian, które wyrażają zróżnicowanie charakterystycznej powierzchniowej warstwy betonu na rozciąganie przy odrywaniu, a także zmiany wytrzymałości betonu podczas zginania;

- Określenie zmian zachodzących w wytrzymałości betonu w wyniku łączynych badań związanych z nagrzewaniem i mrozoodpornością.

Dokonanie wizualnej oceny próbek betonowych pod kątem ewentualnego powstawania na ich powierzchni mikrorys należy odnieść do ilość cykli badawczych, którym poddane były próbki od początku ich cyklu badawczego $\chi_{1}$, do momentu w którym pojawiły się znaczące uszkodzenia struktury betonu $\chi_{2}$. Stan ten odpowiednio można wyrazić zależnościami (5) i (6) wg [8].

$$
\begin{aligned}
& \chi_{1}=\frac{V_{x}}{V_{x o}} \\
& \chi_{2}=\frac{V_{y}}{V_{y o}}
\end{aligned}
$$

gdzie:

$\mathrm{V}_{\mathrm{x}}, \mathrm{V}_{\mathrm{y}}$ - prędkość przejścia fali ultradźwiękowej przez badaną próbkę betonu w kierunku podłużnym $\left(\mathrm{V}_{\mathrm{x}}\right)$ i $\mathrm{w}$ kierunku poprzecznym $\left(\mathrm{V}_{\mathrm{y}}\right)$ - po określonej (procedurą) ilości cykli badawczych.

$\mathrm{V}_{\mathrm{xo}}, \mathrm{V}_{\mathrm{yo}}$ - prędkość przejścia fali ultradźwiękowej przez badaną próbkę betonu w kierunku podłużnym i w kierunku poprzecznym w momencie rozpoczęcia badań.

W początkowym okresie (stadium) zaawansowania procesu uszkodzeń powierzchni betonu $\chi_{1}<1$, a przy wzmocnieniu materiału $\chi_{2}>1$. Jednocześnie $\chi_{2}$ charakteryzuje stan destrukcji betonu w niżej położonych warstwach płyty. 


\section{Modelowanie zjawisk zachodzących na powierzchni płyty pod wpływem zmian temperatury}

Modelowanie zjawisk termicznych wiążących się z przepływem ciepła w płycie betonowej nawierzchni wyznaczyć należy sporządzając bilans termiczny nawierzchni dla określonych warunków geograficznych. Ogólne równanie układu związanego z bilansem cieplnym można przedstawić zależnością (7) wg [1].

gdzie:

$$
R+P+F_{o}+(M * G)=0
$$

$\mathrm{R}$ - wielkość radiacji słonecznej, która rozumiana jest jako różnica pomiędzy zaabsorbowaną energią promieniowania słonecznego krótkofalowego w zakresie $0,3 \div 3 \mu \mathrm{m}$ mierzonych przy powierzchni ziemi;

P - ilość ciepła uzyskanego lub rozchodowanego w kontakcie z powierzchnią ziemi jako rezultat procesów mających turbulentny charakter;

Fo - ilość ciepła (objętościowego) zawartego pomiędzy powierzchnią płyty i jej głębszymi przekrojami lub określonymi warstwami podłoża gruntowego;

$\mathrm{M}^{*} \mathrm{G}$ - wielkość ciepła przechodzącego w parę wodną lub kondensacja pary na drodze przemiany masy parowania wody $\mathrm{M}$ na ciepło parowania $\mathrm{G}$.

Podstawowym składnikiem równania (7) jest radiacja słoneczna, a zależność wyraża prawo zachowania energii w procesach termodynamicznych oraz sposób rozkładu ciepła zachodzącego na powierzchni ziemi pod wpływem tej radiacji [1]. Ideowy proces przepływu ciepła w nawierzchni przedstawiono na rys. 1.

a)

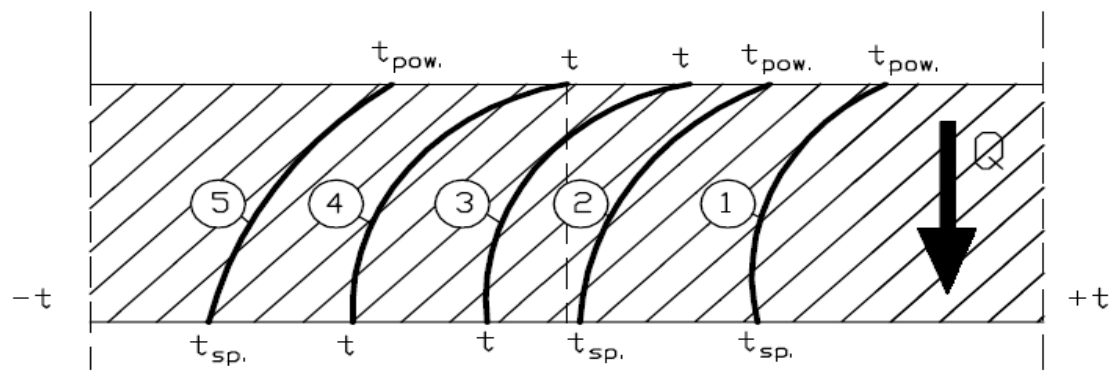

b)

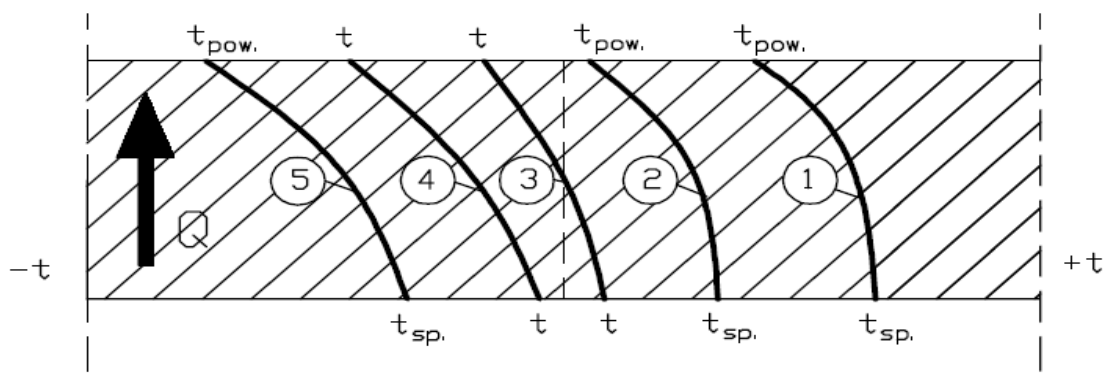

Rys. 1 Możliwe przypadki rozkładu temperatur w nawierzchni betonowej: wariant a) strumień ciepta $Q$ przechodzi z tej powierzchni do niższych warstw; wariant b) strumień ciepta $Q$ przemieszcza się w odwrotnym kierunku. 
Thermal resistance of airfield concrete pavements and consequences...

Termiczna odporność betonowych nawierzchni lotniskowych i jej skutki...

Ocenę termicznej odporności betonu nawierzchniowego można otrzymać konstruując modele nawierzchni uwzględniające jedno- i wielokierunkowe przepływy ciepła w złożonym układzie warstwowym [2].

Charakterystyki zmian parametrów mechanicznych warstwy powierzchniowej płyt nawierzchni betonowej można dokonać analizując:

- wytrzymałość betonu, poddanego cyklom nagrzewania zgodnie z [NO-17A200], na zginanie;

- wytrzymałość warstwy powierzchniowej na odrywanie metodą ,pull off”.

Urządzenie służące do określania wytrzymałości wierzchniej warstwy betonu na odrywanie metodą ,pull off” pokazano na rys. 2.

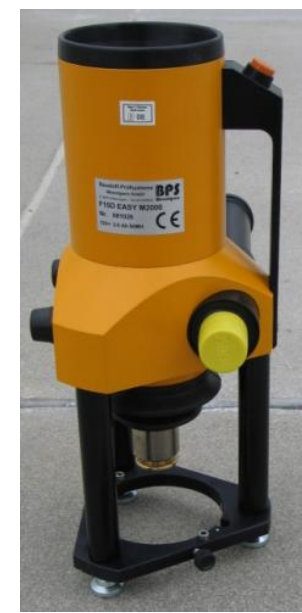

Rys. 2 Urzadzenie do badania wytrzymatości betonu na odrywanie metoda , pull off"

Wytrzymałość na zginanie betonu nawierzchniowego określono dla betonów poddanych cyklicznemu działaniu temperatury. Cykliczne działanie temperatury symulowało oddziaływanie statku powietrznego na nawierzchnie lotniskowe. Analizowano dwie serie betonu cementowego. Pierwszą stanowił beton o standardowym składzie (cement, kruszywo, woda i domieszki) - R. Natomiast w przypadku serii $\mathrm{M}$ część kruszywa drobnego została zastąpiona dodatkiem ceramicznym odpornym na działanie zróżnicowanych temperatur. Na tym etapie wytrzymałość na zginanie może być wyznacznikiem trwałości użytkowej nawierzchni i wyrażać się będzie zdolnością konstrukcji do przenoszenia obciążenia statycznego, dynamicznego i termicznego w zależności od klasy betonu i jego stanu wilgotnościowego [6].

Wytrzymałość na odrywanie warstwy powierzchniowej metodą „pull off” zgodnie $\mathrm{z}$ [4] nie powinna być niższa niż 5\% w stosunku dla poszczególnych klas betonu tj. 2,0 $\mathrm{MPa}$ - dla nawierzchni eksploatowanych w okresie do 10 lat oraz 1,8 $\mathrm{MPa}$ - dla nawierzchni użytkowanych w okresie dłuższym niż 10 lat. 


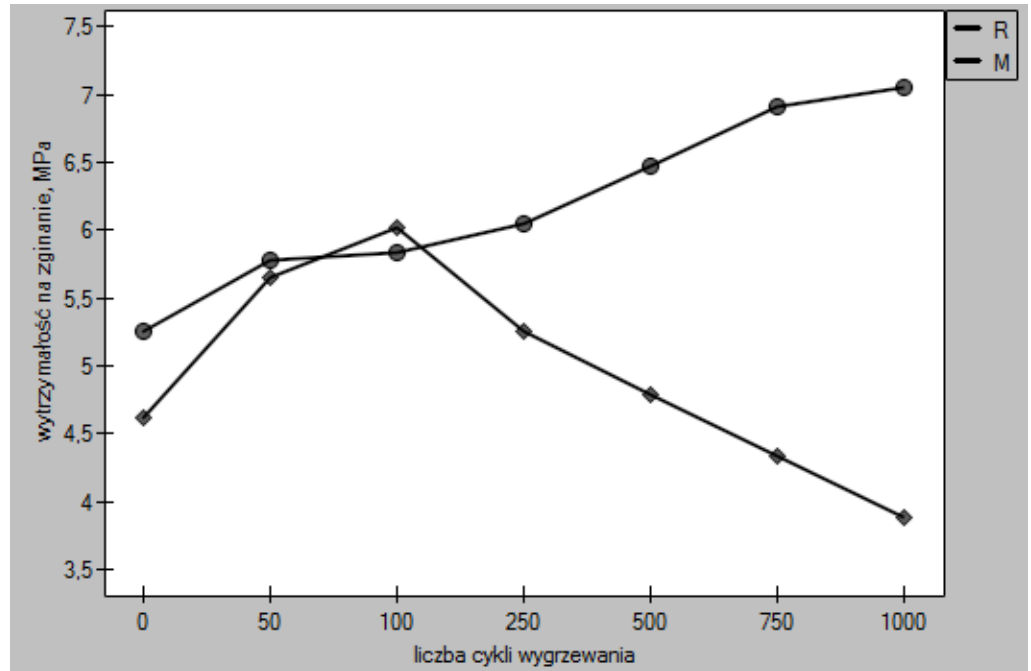

Rys. 3 Średnia wytrzymatość na zginanie betonu R i M w funkcji liczby cykli wygrzewania.

Proponowane kryteria termicznej odporności betonu nawierzchniowego przedstawiono w tabeli 1.

Tab. 1 Kryteria termicznej odporności betonu nawierzchniowego

\begin{tabular}{|c|c|c|c|c|}
\hline \multirow{2}{*}{$\begin{array}{l}\text { Stan wilgotności } \\
\text { badanego betonu }\end{array}$} & \multicolumn{4}{|c|}{ Metoda badań } \\
\hline & \multicolumn{2}{|c|}{ Ocena wizualna } & $\begin{array}{c}\text { Metoda } \\
\text { ultradźwiękowa }\end{array}$ & $\begin{array}{c}\text { Wytrzymałość } \\
\text { na zginanie }\end{array}$ \\
\hline $\begin{array}{c}\text { Próbki o wilgotności } \\
\text { naturalnej w } \\
\text { warunkach } \\
\text { laboratoryjnych } \\
\end{array}$ & Brak mikrorys & $\begin{array}{l}400 \text { cykli bez } \\
\text { widocznych } \\
\text { uszkodzeń }\end{array}$ & $\begin{array}{l}\text { Obniżenie } \\
\text { V(x) oraz } \\
\text { V(y) o } 5 \%\end{array}$ & $\begin{array}{c}\text { Obniżenie } \\
\text { wytrzymałości } \\
\text { na zginanie do } \\
15 \%\end{array}$ \\
\hline Próbki wilgotne & $\begin{array}{c}\text { Powstanie } \\
\text { mikrorys po 4-5 } \\
\text { cyklach } \\
\text { badawczych } \\
\end{array}$ & \begin{tabular}{|c|} 
Uszkodzenie \\
betonu po $250-$ \\
270 cyklach \\
badawczych \\
\end{tabular} & $\begin{array}{l}\text { Obniżenie } \\
\text { V(x) i V(y) } \\
\text { o } 25 \div 30 \%\end{array}$ & $\begin{array}{c}\text { Próbki } \\
\text { betonowe } \\
\text { uszkodzone }\end{array}$ \\
\hline $\begin{array}{l}\text { Próbki po } \\
\text { wcześniejszych } \\
\text { badaniach } \\
\text { mrozoodporności }\end{array}$ & $\begin{array}{c}\text { Powstanie } \\
\text { szczelin w } \\
\text { próbkach po 1-2 } \\
\text { cyklach } \\
\text { badawczych } \\
\end{array}$ & $\begin{array}{l}\text { Uszkodzenie } \\
\text { betonu po } \\
\text { 35- } 40 \text { cyklach } \\
\text { badawczych }\end{array}$ & - & $\begin{array}{l}\text { Próbki } \\
\text { betonowe } \\
\text { uszkodzone }\end{array}$ \\
\hline
\end{tabular}

\section{Mechanizm niszczenia betonu pod wpływem działania wysokich temperatur i warunków ruchu po nawierzchni.}

Mechanizm niszczenia betonu nawierzchniowego, będącego wynikiem naturalnych procesów termicznych zachodzących $\mathrm{w}$ atmosferze oraz jego skutków dla nawierzchni betonowej, w początkowym stadium objawia się jako odspojenie minimalnej grubości warstwy na górnej powierzchni płyty.

Proces niszczenia tej warstwy może być rozpatrywany z punktu widzenia teorii sprężystości - w tym przypadku największych odkształceń Mariotta [8]. 
Thermal resistance of airfield concrete pavements and consequences...

Termiczna odporność betonowych nawierzchni lotniskowych i jej skutki...

Zgodnie $\mathrm{z}$ tą teorią, kruche odkształcenie materiału (odspojenie warstwy nawierzchni) wiąże się z największym wydłużeniem w odpowiedniej temperaturze badań w warunkach czystego rozciągania. Zależność tę można przedstawić w postaci [8]:

$$
\varepsilon_{z}=-\frac{2 \mu(t)}{E(t)} \sigma(z)+\beta t(z)
$$

Jednocześnie wielkość $\varepsilon_{\mathrm{z}}$ nie powinna przekraczać granicy $\varepsilon_{\mathrm{p}}$. Dopuszczalne odkształcenie $\varepsilon_{\mathrm{p}}$ betonu można wyrazić w postaci [8]:

$$
\varepsilon_{p}=\frac{R_{r}(t)}{E(t)}
$$

gdzie:

$\mathrm{R}_{\mathrm{r}}(\mathrm{t})$ - wytrzymałość betonu na czyste rozciąganie w odpowiedniej temperaturze. $\mathrm{E}(\mathrm{t})$ - moduł sprężystości betonu określony dla odpowiedniej temperatury badań.

Wykorzystując zależności (8), (9) po przekształceniach uzyskuje się kryterium naprężenia dopuszczalnego na ścinanie w warstwie przypowierzchniowej betonu nawierzchniowego [8].

$$
\sigma_{\dot{\mathrm{s}}}(z)=-\frac{R_{r}(t)}{2 \mu(t)}
$$

Symbole przyjęte we wzorach (8), (9), (10) i (11) oznaczają:

$\mathrm{Rr} \quad$ - wytrzymałość betonu na czyste rozciąganie w odpowiedniej temperaturze badań;

$\mu(\mathrm{t})$ - współczynnik Poissona betonu określony $\mathrm{w}$ odpowiedniej temperaturze badań;

E ( $\mathrm{t}$ ) - moduł sprężystości betonu określony dla odpowiedniej temperatury badań;

$\beta(\mathrm{t})$ - współczynnik termicznego odkształcenia (wydłużenia)

$\sigma_{\mathrm{d}}(\mathrm{z})$ - naprężenie dopuszczalne w betonie na kierunku osi z.

Innym możliwym przypadkiem uszkodzenia betonu w wyniku oddziaływań termicznych są naprężenia normalne $\sigma_{d}$ występujące na kierunkach osi x i y. Wyrazić je można w postaci zależności (11) [8].

$$
\sigma_{d}(z) \leq R_{r}(t)
$$

Konstruując warstwy betonu o zwiększonej termicznej odporności należy mieć na uwadze spełnienie warunków (10) i (11) jednocześnie. Doświadczenia wynikające z eksploatacji takich nawierzchni betonowych, do których należą: płaszczyzny prób silników, końcowe odcinki dróg startowych i inne, wskazują na uzasadnioną potrzebę stosowania na tych fragmentach nawierzchni, cienkich warstw izolacyjnych wykonanych z materiałów o wysokiej odporności termicznej [6].

Teoretyczne modele termicznych warstw konstrukcyjnych nawierzchni betonowej, zwracają uwagę na jakościową stronę procesu uszkodzeń. Zagadnienia te nie zawsze daje się wyjaśnić w stosunkowo prostym, jednokierunkowym przepływie ciepła w układzie konstrukcyjnym nawierzchni. Proces przepływu ciepła $\mathrm{w}$ nawierzchni jest $\mathrm{w}$ istocie przepływem wielokierunkowym, który znacznie komplikuje opis i analizę tego zjawiska. Stosunkowo niska przewodność termiczna betonu $\mathrm{W}$ wyniku tych naturalnych oddziaływań jest przyczyną uszkodzeń nawierzchni. 
W miarę upływu czasu odspojenia powierzchniowe rozwijają się prowadząc do pogłębienia zjawisk destrukcyjnych. Zjawisko powierzchniowej, rozległej destrukcji występuje częściej na nawierzchni w strefach, które podczas budowyukładania betonu, były nadmiernie zagęszczone i w efekcie przewibrowane. W miejscach tych występuje najczęściej zjawisko „bleedingu” nawierzchni. Blaszkowate odspojenia warstwy powierzchniowej betonu świadczą o utracie stabilności górnej warstwy betonu. Wystąpienie uszkodzeń temperaturowych betonu może mieć również charakter gwałtowny. W wyniku działań temperatury ulegają $w$ szczególności zmianie wytrzymałość i odkształcenia, tj. zmiana właściwości fizycznych i mechanicznych betonu. Proces uszkodzeń nawierzchni betonowych różni się dość istotnie od procesu zniszczenia ciał jednorodnych. Stopień odwodnienia tworzywa betonowego pod wpływem działania temperatury powietrza prowadzi do zmian objętości tego tworzywa, możliwa jest wówczas zmiana geometrii siatki krystalograficznej, a w następstwie powyższego, zwiększenie kruchości materiału. Proces uszkodzeń zaczyna się od utraty spójności pomiędzy zaczynem cementowym, a powierzchnią poszczególnych ziaren kruszywa, powstają wówczas mikroszczeliny na granicy tych składników. Złożoność procesu uszkodzeń potęguje się w sytuacji, gdy beton nawierzchniowy jest wilgotny. W wyniku naturalnych procesów atmosferycznych $\mathrm{w}$ betonowej nawierzchni powstają nieregularne „pola wilgotności”. Wielkość tych pól zależy od intensywności parowania „wolnej wody” z betonu, procesu intensywnego oddziaływania strugi gazów emitowanych $\mathrm{z}$ dysz statków powietrznych po przekroczeniu na płycie betonowej temperatury $200^{\circ} \mathrm{C}$. Temperatura taka i wyższa na płycie występuje przy emisji strumienia gorących gazów spalinowych [6]. Temperatury otoczenia $\mathrm{i}$ temperatury wymuszone prowadzą do koncentracji wilgoci w postaci wspomnianych „pól wilgotności”, zwiększając ciśnienie międzycząsteczkowe. Superpozycja tych naprężeń wilgotnościowych i występujących często jednocześnie obciążen podstawowych prowadzi do stanu wytężenia betonu mającego niestabilny charakter, a w stanie granicznym do jego uszkodzenia. Analiza modelowa procesu zniszczenia termicznego betonów nawierzchniowych, wiąże skutki tego procesu $\mathrm{z}$ działaniem powstałej $\mathrm{w}$ wyniku zachodzących procesów fizycznych tj. działaniem aktywnej pary wodnej i zaistnieniem tak zwanego „efektu Rebindera” [8] związanego ze zjawiskiem naprężenia powierzchniowego i wystąpieniem energii powierzchniowej.

Efekt Rebindera polega na zmniejszaniu gęstości energii powierzchniowej, a tym samym napięcia powierzchniowego na brzegu fazy stałej $\mathrm{w}$ wyniku adsorpcji substancji powierzchniowo czynnej. Dotyczy to głównie materiałów o rozwiniętym systemie kapilarno-porowatym, do których należy również beton. Zmniejszenie gęstości energii w omówionym efekcie, powoduje powstanie dodatkowych mikroszczelin $\mathrm{W}$ ośrodku (rozszczelnienie struktury) i w konsekwencji zmniejszenie wytrzymałości materiału na obciążenia mechaniczne.

$\mathrm{Na}$ proces powstawania uszkodzeń nawierzchni betonowej i ich rozwój mają wpływ omawiane zjawiska termicznych oddziaływań naturalnych, obciążenie zasadnicze konstrukcji i stan wilgotnościowy nawierzchni. Działanie temperatury na nawierzchnię oprócz odparowania nadmiaru wilgoci, powoduje przemieszczanie w strukturze betonu procesów filtracyjnych i przemieszczanie się pary wodnejczęsto o podwyższonym ciśnieniu. Zjawisku temu towarzyszą ponadto zjawiska erozyjne oraz efekty abrazyjne i kawitacyjne. Na granicy stref wilgotnej i suchej tworzą się pola naprężeń termicznych. W sytuacji, gdy wartość naprężeń rozciągających będzie wyższa niż naprężenia dopuszczalne, wówczas w objętości 
Thermal resistance of airfield concrete pavements and consequences...

Termiczna odporność betonowych nawierzchni lotniskowych i jej skutki...

betonu tworzy się siatka mikrorys o kierunku prostopadłym do kierunku głównych naprężeń rozciągających. $\mathrm{W}$ tym momencie uszkodzenie betonu jest konsekwencją działania naprężeń stycznych skierowanych pod pewnym kątem do powstałych pęknięć strukturalnych.

Te złożone wymagania dotyczące powierzchni powinny być wyznacznikiem zagadnień związanych $\mathrm{z}$ projektowaniem konstrukcyjnym $\mathrm{i}$ technologicznym nawierzchni betonowych. Jednocześnie nasuwa się pytanie o granice działania technicznego, które ma doskonalić warstwę powierzchni betonowej płyty. Jest oczywiste, że kryterium doskonalenia jest bezpieczeństwo ruchu naziemnego na lotnisku i eliminacja zagrożeń związanych $\mathrm{z}$ możliwością awarii jednostki napędowej statku powietrznego. Oczekiwana struktura powierzchni nawierzchni wpływa na dobór odpowiednich materiałów, procesu wbudowywania, a w tym kontekście mechanizmu zużycia nawierzchni. Intensywność zużycia nawierzchni w przewidywanym okresie czasu nie jest równomierna, a czas normatywny trwałości jest czasem postulowanym. Warstwę wierzchnią płyty betonowej, która bezpośrednio wpływa na proces utrzymania nawierzchni w czasie ma nie tylko jej kształt, chropowatość- wyrażona przez współczynnik tarcia (w dawnej nomenklaturze terminologicznej współczynnik sczepności) oraz jej wygląd. Na rys. 4. przedstawiono widok struktury powierzchniowej warstwy nawierzchni betonowej $\mathrm{z}$ intensywnie eksploatowanego fragmentu, tj. płaszczyzny prób silników.

W pewnych sytuacjach zaobserwować można dynamiczny proces zmęczenia betonu poddanego intensywnym oddziaływaniom temperaturowym. Istotne stwierdzenia dotyczące tego problemu przedstawiono w pracy [8].

Analizując ten poglądowy model warstwy wierzchniej płyty betonowej daje się zauważyć różnice, które powstają niezależnie od woli realizatora budowanej nawierzchni i są wynikiem procesu technologicznego realizowanego w dużej skali. Warunki eksploatacji tj. ruch statków powietrznych po nawierzchni zmieniają mikrostrukturę ukształtowanej w sposób roboczy, nie idealnej warstwy wierzchniej. Proces ten zachodzi zazwyczaj w długim okresie czasu, gdy reżimy technologiczne budowy nawierzchni są przestrzegane. Jednak niezależnie od

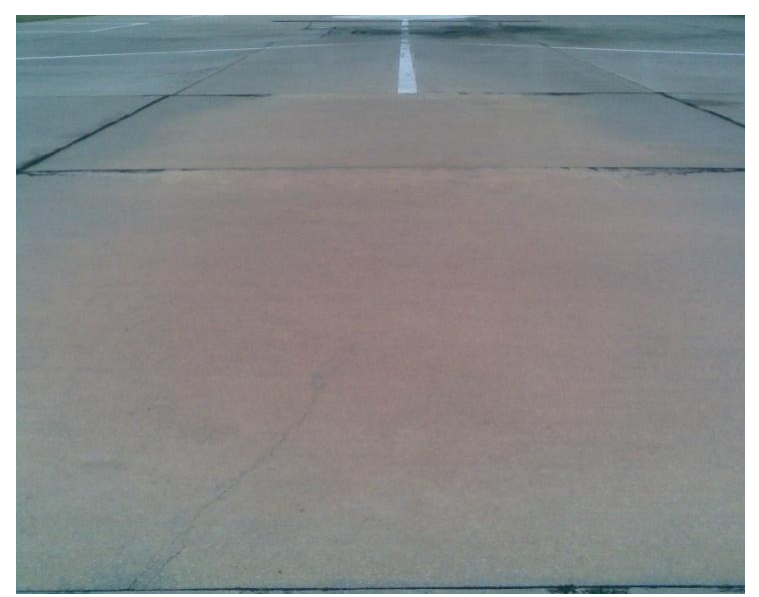

Rys. 4 Zmiany struktury warstwy wierzchniej nawierzchni betonowej pod wpływem warunków eksploatacyjnych. [6] 


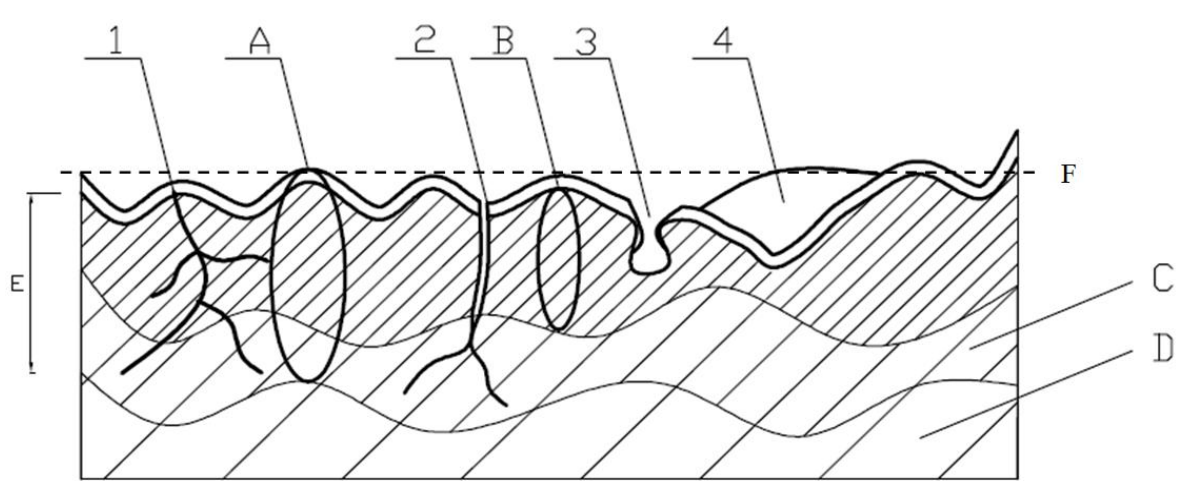

Rys. 5 Model warstwy wierzchniej z betonu cementowego nawierzchni betonowej po jej wbudowaniu oraz $w$ pierwszym okresie jej eksploatacji.

Przyjęte oznaczenia: A - struktura warstwy wierzchniej, B - część warstwy wierzchniej poprawnie zagęszczona, C - strefa wewnętrzna warstwy wierzchniej, D - strefa środkowa warstwy konstrukcyjnej-rdzeń warstwy, E - grubość warstwy wierzchniej, F - teoretyczna niweleta nawierzchni, 1 - mikroszczeliny, 2 - szczelina powierzchniowa, 3 - pory, 4 - naturalny, losowy ubytek mieszanki betonowej.

dobrze ukształtowanej warstwy wierzchniej, ruch po nawierzchni powoduje jej zużycie, które objawia się $\mathrm{w}$ postaci zmian umieszczonych: objętościowo, powierzchniowo, liniowo lub masowo.

\section{Zmiany struktury warstwy wierzchniej płyty betonowej w procesie jej eksploatacji.}

Nawierzchnie lotniskowe podlegają złożonemu, fizycznemu kompleksowemu obciążeniu jej górnej powierzchni, w tym również naprężeń pochodzących od wymuszonych procesów emitowanych gazów spalinowych. Niżej położone warstwy betonowej nawierzchni tym procesom podlegają $\mathrm{w}$ znacznie ograniczonym zakresie. Jest to przyczyna powstawania wewnętrznych naprężeń, zwykle o różnoimiennych znakach. W proces zmian struktury od naprężeń temperaturowych należy włączyć ruch statków powietrznych po nawierzchni. W dotychczasowej praktyce eksploatacyjnej podstawowym kryterium oceny nawierzchni betonowych na lotniskach były: wytrzymałość składników i wykonanych $\mathrm{z}$ tych składników warstw oraz $\mathrm{w}$ znaczeniu eksploatacyjnym: nośność, równość, szorstkość. Mniejszą uwagę zwracano na czynniki strukturalne spowodowane warunkami eksploatacyjnymi, a w szczególności na własności powierzchni roboczych płyt nawierzchniowych, których stan ma charakter zużycia trybologicznego i nietrybologicznego. Zużycie nawierzchni jest uszkodzeniem jej powierzchni polegającym na stopniowym zmniejszaniu się warstwy wierzchniej poddanej ruchowi statków powietrznych lub reakcjami na przykład chemicznymi. Ten rodzaj zużycia jest również następstwem takich zjawisk jak: korozja, pękanie, zmęczenie materiału.

Proces trybologicznego zużycia dotyczy wszystkich materiałów występujących w przyrodzie i technice. Intensywność tego zjawiska zależy od odporności warstwy 
Thermal resistance of airfield concrete pavements and consequences...

Termiczna odporność betonowych nawierzchni lotniskowych i jej skutki...

wierzchniej, rodzaju oddziaływania i jego intensywności. Intensywność zużycia zależy od ilości wykonywanych operacji lotniczych w analizowanym okresie. W przypadku nawierzchni lotniskowych szczególnie intensywne zużycie występuje na końcowych odcinkach dróg startowych - głównie w operacji lądowania, gdzie dodatkowo występuje oddziaływanie dynamiczne. W tej strefie tego elementu nawierzchni mają miejsce zjawiska: zużycia ściernego, spallingu (łuszczenia, które narasta stopniowo wokół defektów strukturalnych warstwy wierzchniej) i omawianego wcześniej efektu Rebindera. Wystąpienie zużycia nietrybologicznego w nawierzchni polega na zjawiskach: korozji, ablacji, erozji, abrazji, kawitacji, zużycia cieplnego i odkształceń. Wszystkie te zjawiska występują w różnym zakresie, na wybranych powierzchniach współpracujących ze statkami powietrznymi i są następstwem naturalnych zjawisk klimatycznych. Proces zniszczenia spallingowego zobrazowano na rys. 6.

Wymienione rodzaje uszkodzeń trybologicznych i nietrybologicznych wymagają skutecznych rozwiązań $\mathrm{w}$ technice inżynierii powierzchni, które $\mathrm{w}$ budowie nawierzchni lotniskowych czy drogowych są w początkowej fazie rozwoju. Trudności w zaproponowaniu skutecznych rozwiązań konstrukcyjnotechnologicznych zwielokrotniają się w sytuacji gdy oddziaływania te występują łącznie- a tak jest najczęściej w warunkach eksploatowania obiektu.

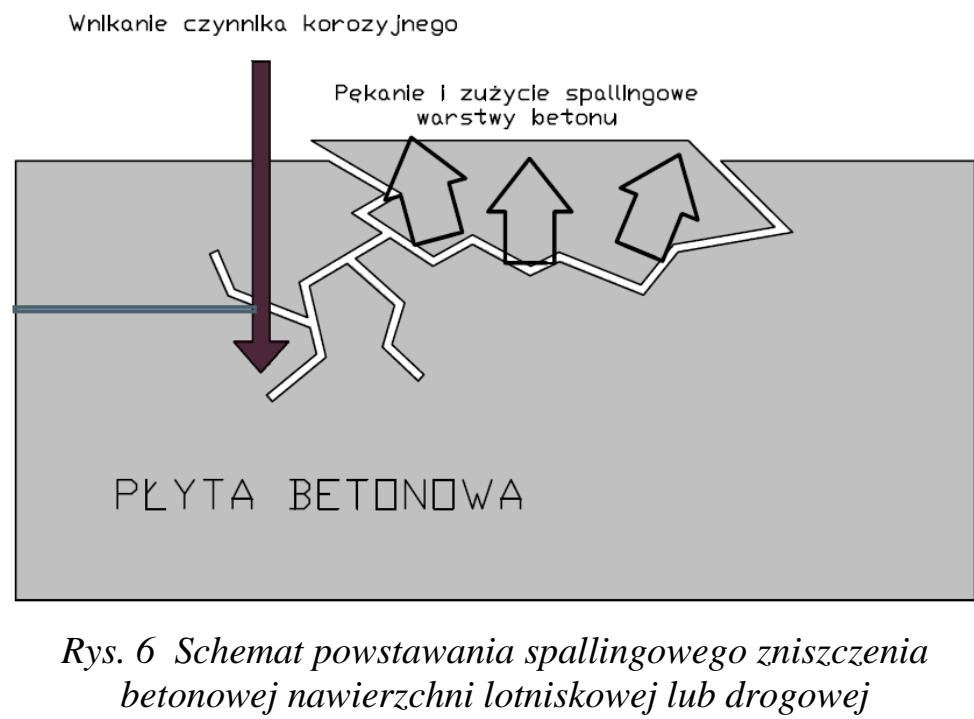

\section{Podsumowanie}

Problem naprężeń termicznych $\mathrm{w}$ betonowych nawierzchniach lotniskowych nie został do chwili obecnej dostatecznie wyjaśniony, zarówno w kontekście wymiarowania konstrukcyjnego, jak również w aspekcie skutków eksploatacyjnoutrzymaniowych. Obecnie obserwuje się skutki tych oddziaływań, a poczynania ograniczające lub naprawcze tych stanów, wymagają znajomości z zakresu fizyki budowli, przepływów ciepła i zagadnień inżynierii materiałowej. Najbardziej dotkliwym problemem jest ograniczenie uszkodzeń wierzchniej warstwy płyty 
betonowej tj. złuszczeń powierzchniowych, które występują $\mathrm{w}$ postaci blaszek i niewielkich odprysków. Te niewielkie objętościowe uszkodzenia są zasadniczym problemem, który istotnie może ograniczyć eksploatację nawierzchni. Istnieje rzeczywiste zagrożenie zassania tych luźno zespolonych z podłożem cząstek do dysz wlotowych statków powietrznych. Inne postacie uszkodzeń głębszych warstw betonu choć ważne, to jednak z punktu widzenia pracy całej konstrukcji, dla bezpieczeństwa ruchu po nawierzchni mają mniejsze znaczenie. W pracy przedstawiono wybrane zagadnienia naprężeń termicznych $\mathrm{w}$ nawierzchniach betonowych, spowodowane tylko cyklicznymi, naturalnymi zmianami temperatury otoczenia w rocznych i dobowych okresach tych zmian.

Tak, jak zaznaczono we wstępie, nie uwzględniono w publikacji naprężeń termicznych spowodowanych emisją gazów spalinowych z dysz eksploatowanych statków powietrznych- co dodatkowo komplikuje sprawę. W publikacji omówiono zjawiska zachodzące w wierzchniej warstwie płyty, to właśnie one decydują często o możliwości bezpiecznej eksploatacji nawierzchni. W pracy betonowej nawierzchni lotniskowej daje się wyróżnić dwie strefy, które charakteryzują pracę całej konstrukcji, są to: warstwa wierzchnia i niżej położone warstwy stanowiące rdzeń konstrukcji. Chociaż konstrukcja płyty nawierzchniowej stanowi monolityczną strukturę, to jednak udział w przenoszeniu naprężeń termicznych jest różny i zależy od grubości tych warstw. Sugeruje to potrzebę innego podejścia do rozwiązań projektowych i realizacyjnych, których istotą jest dobór takich kompozycji materiałowych odpornych na działanie czynników atmosferycznych i wymuszonych obciążeń termicznych, które mają na uwadze wysoką trwałość i niezawodność tych konstrukcji. W związku $\mathrm{z}$ tym, obowiązujące normy i wytyczne techniczne powinny być uzupełnione o wymagania i kryteria właściwe dla materiałów charakteryzujących się wysoką odpornością termiczną. Kryteria termicznej odporności materiałów stosowanych do betonowych nawierzchni lotniskowych powinny być bardziej szczegółowe i rozwinięte wraz $\mathrm{z}$ opracowaniem dla nich właściwych metod badawczych. Jedną z metod wyznaczenia naprężeń termicznych i skutków ich oddziaływań dla nawierzchni betonowych powinien być bilans termiczny układu konstrukcji sporządzany na etapie projektu dla każdego obiektu planowanego do realizacji. Bilans ten powinien uwzględniać geograficzne warunki położenia tego obiektu. Warunki przemieszczania pary wodnej $\mathrm{w}$ konstrukcji, której skutki działania w postaci występującego nadciśnienia wymuszają, by w modelu nawierzchni uwzględnić zjawiska termodynamicznego przepływu tego medium. Rozpoznanie szeregu zjawisk występujących w lotniskowej nawierzchni betonowej, które dotychczas nie zostały zidentyfikowane przynosi często dotkliwe i nieoczekiwane trudności w pracy konstrukcji nawierzchni i otaczającym je środowisku. Pozostaje jednak pytanie i ocena procesów występujących zmian płyty nawierzchni lotniskowej, które wywołane zostały zmianami klimatycznymi. A także kiedy i w jakich okolicznościach należy uznać, że w wyniku zmian struktury i zmian występujących $\mathrm{w}$ górnej roboczej powierzchni płyty nawierzchnia powinna być wyłączona z eksploatacji. 
Thermal resistance of airfield concrete pavements and consequences...

Termiczna odporność betonowych nawierzchni lotniskowych i jej skutki...

\section{Literatura:}

[1] Nita P.: Betonowe nawierzchnie lotniskowe. Teoria i Wymiarowanie Konstrukcyjne. Instytut Techniczny Wojsk Lotniczych, Warszawa, 2005.

[2] Nita P.: Budowa i utrzymanie nawierzchni lotniskowych, Wydawnictwa Komunikacji i Łączności, Warszawa, 2008.

[3] Staniszewski B.: Wymiana ciepła. Podstawy teoretyczne. Państwowe Wydawnictwa Naukowe, 1980.

[4] NO-17-A204:2015 Nawierzchnie lotniskowe. Nawierzchnie lotniskowe $\mathrm{z}$ betonu cementowego. Wymagania i metody badań.

[5] Graczyk M.: Nośność konstrukcji nawierzchni wielowarstwowych w krajowych warunkach klimatycznych. Praca habilitacyjna, Politechnika Warszawska, 2013.

[6] Linek M.: Beton nawierzchniowy o podwyższonych parametrach fizycznych i mechanicznych na działanie wymuszonych obciążeń temperatury. Praca doktorska, Politechnika Świętokrzyska, 2013.

[7] Marszałek J.: Budowa lotnisk cz. II. Obliczenia nawierzchni. Skrypt Wojskowej Akademii Technicznej, 1984.

[8] Trigoni B. E.: Struinnaja erozja aerodromow. Transport. Moskwa, 1981.

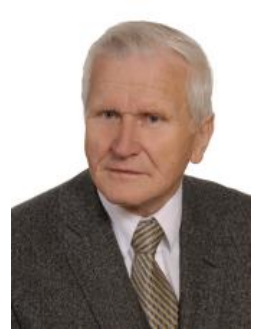

prof. dr hab. ini. Piotr Nita - pracuje jako profesor nadzwyczajny $w$ Instytucie Technicznym Wojsk Lotniczych w Warszawie oraz na Politechnice Świętokrzyskiej w Kielcach. Zainteresowania naukowe obejmuja budownictwo komunikacyjne, a w szczególności projektowanie, budowe $i$ utrzymanie lotnisk.

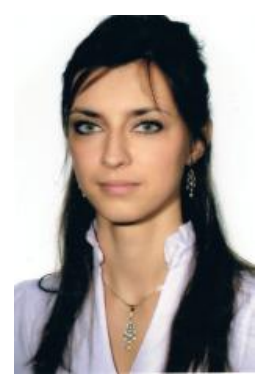

dr inz. Matgorzata Linek - pracuje jako adiunkt na Politechnice Świętokrzyskiej w Kielcach. Uzyskała tytut doktora nauk technicznych $w$ dyscyplinie budownictwo $w$ specjalności budowa dróg $i$ lotnisk. Zainteresowania naukowe obejmuja aspekty trwałości i niezawodności nawierzchni lotniskowych.



mgr inz. Patrycja Piotrowska-Nowak - uzyskała tytut magister inżynier budownictwa w specjalności budowa dróg na Wydziale Budownictwa $i$ Architektury Politechniki Swiętokrzyskiej w Kielcach. Zainteresowania naukowe obejmuja zagadnienia trwatości nawierzchni lotniskowych. 